\title{
Presentation of the Howland Award to Josef Warkany
}

\author{
JAMES G. WiLson ${ }^{[3]}$ \\ Children's Hospital Research Foundation, Cincinnati, Ohio, USA
}

I am deeply grateful to the American Pediatric Society for allowing me to share in this occasion which honors my teacher, associate, and friend, JosEF WARKANY.

He was and still is my teacher, not in any classroom sense, but more in the manner of the Socratic scholar who, because of the breadth of his knowledge and the depth of his understanding, attracted around him a coterie of followers eager to learn by personal association. For this reason. I made the first of a series of pilgrimages to the Children's Hospital Research Foundation of Cincinnati 24 years ago to study with Joser WARKANY. Those long sessions over the microscope and the hot slide projectors, the latter radiating heat into the already less-than-congenial Midwestern summer atmosphere, were enough to try, but not to dispel, the enthusiasm of a young embryologist who had come to learn from the man who knew best what the science of teratology was all about.

Of course, Dr. Warkany would quickly point out that he did not originate the science of teratology. He would explain that it was already a voluminous descriptive science by the beginning of the present century, and that it had been the subject of some analytical thought and of occasional experimental study since the time of William Harvey in the 17th century.

Those who have themselves been involved with the subject, however, know very well that beginning about 1940 there was an abrupt transition, from what was a relatively obscure discipline concerned with abnormal development in lower animals, to a vigorous experimental science with direct applicability to human problems. It was in this year, 1940, that Dr. WARKANY published the first of a long series of reports that established the fact that the mammalian embryo was not impervious to adverse influences from the environment. His outstanding successes in such laboratory studies, together with his prior and concurrent involvement in clinical teratology, made all the more compelling his belief, that extraneous influences also could reach the human embryo and divert the cause of normal development in this species, previously assumed to be exempt from most environmental adversity. Confirmation came all too soon from Australia, where the rubella virus in 1941 had made it tragically clear that the human embryo was vulnerable to extrinsic agents.

Over the succeeding years he has further defined the susceptibility of the mammal in utero to various nutritional deficiencies, to radiations, to salicylate poisoning, and to antibiotic overdosage. I venture that there is not a scientifically informed person in this audience who is not familiar with some of these pioneering studies. As pediatricians you are equally aware of Dr. WARKANY's contributions to clinical teratology, of his careful delineation of several congenital diseases, and of his timely concern with new areas of inquiry, such as human cytogenetics, as well as the more established areas, such as mental deficiency. Some of you are also aware that he was for a number of years active in pediatric endocrinology, both as clinician and as writer, the latter as recently as 1959 [1]. The real breadth of Dr. WARKANY's pediatric acumen, however, may best be exemplified by his recognition of hypersensitivity to mercury as the causative factor in pink disease or acrodynia.

Although hardly an organizational man, JOE WARKANY has made a contribution in this sphere as well. He helped organize the Teratology Society, and served as its first president. Within the Children's Hospital Research Foundation he has been instrumental in establishing the Institute for Developmental Research, and currently serves as its Director of Mental Retardation Research.

With these passing references to his scientific accomplishments, I should now like to try to give you an insight into the personality of the man, whom many of you already know as a warm, sympathetic, tolerant 


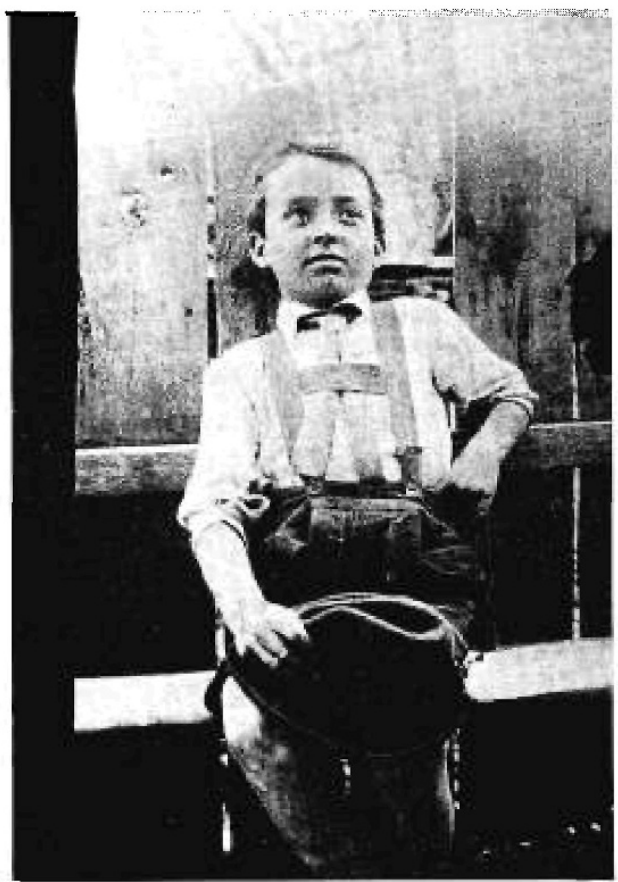

1

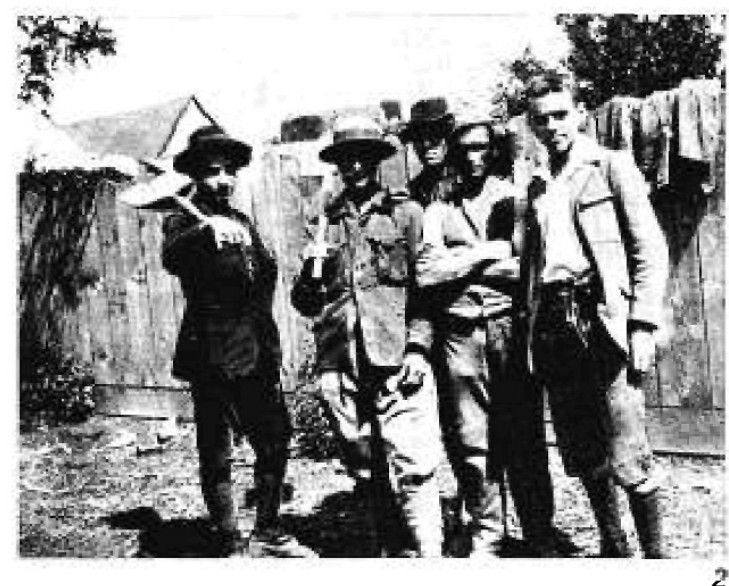

Fig. 1. The young Austrian in Tyrolean garb.

Fig. 2. As a youthful laborer (at left) during World War 1 .

Fig.3. The intent student at the University of Vienna Medical School.

Fig.4. The seasoned world traveler, seen here testing the breeze with a moistened forefinger.

Fig. 5. The lover-of the great out-of-doors, enjoying the scenery with a fellow teratologist during an outing at the King Ranch in Texas.

Fig.6. An etching entitled 'Harvest Time'.

Fig. 7. An etching entitled 'November'. These and several other of Dr. WARKANY's etchings have been exhibited nationally.
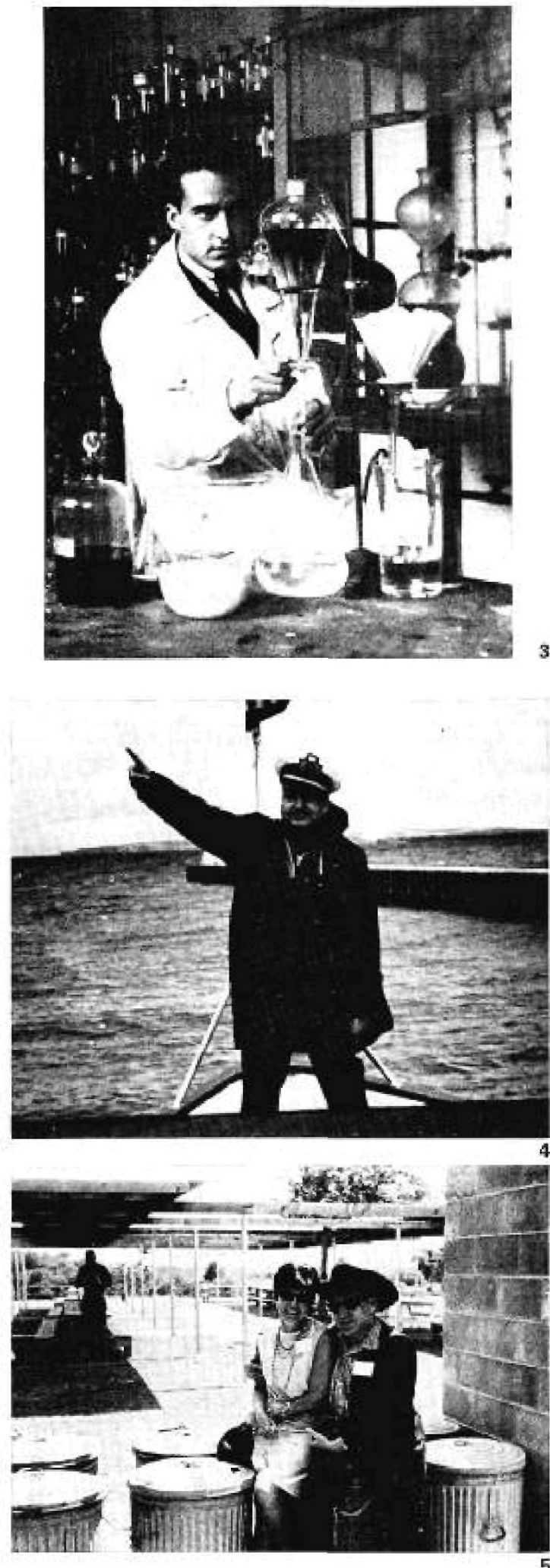

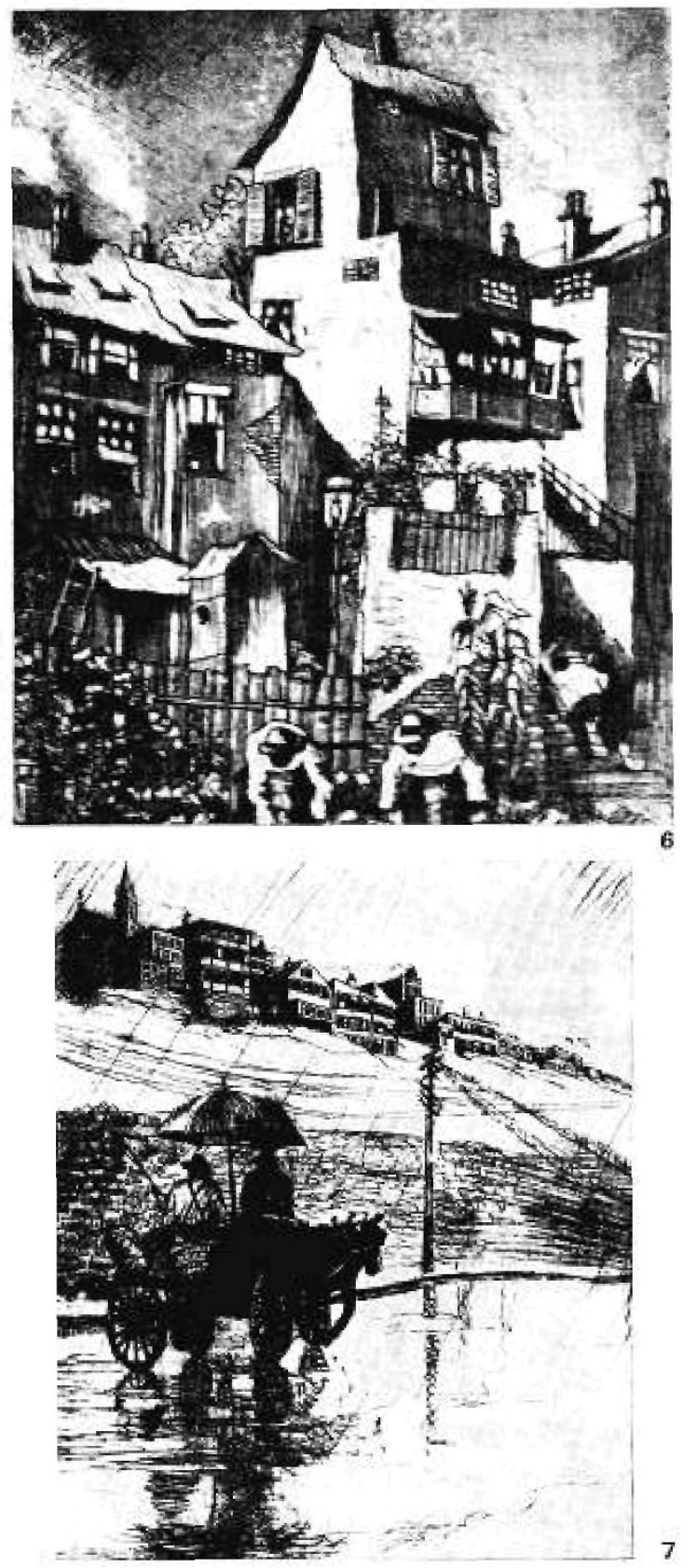

human being with a remarkable sense of humor. $\mathrm{He}$ was born and reared in Vienna and much of his youth was spent in the turbulent times that enveloped that historic city during and following World War I (figs. 1, 2 , and 3). Certainly some of his appreciation for and loyalty to American institutions is an outgrowth of the contrast of which he became acutely aware when he arrived in this country in 1932. He still reminds his friends that we do not really understand the true meaning of personal freedom, and of the worth of the individual, because we have never lived under conditions in which these values were denied or seriously threatened. The one kind of situation that consistently dispells his usual good humor is that in which he recognizes signs of bigotry or infringement on individual rights.

This is not to say that he rigidly adheres to some safe stereotype of attitude or conduct. On the contrary, he approves of rational flexibility, dislikes conformity for its own sake, and is not above poking fun at the stodgy or pretentious. He is able to laugh at minor human frailties-including his own. And now, I hope he will not mind if I presume on that last statement and tell a couple of true anecdotes.

He often used to say that police and fire engine sirens made him nervous. When asked why, he would recall the difficulty he had after first coming to this country in understanding certain traffic rules. Particularly baffling were fire and police vehicles that rushed upon his car from the rear, with sirens wailing, lights flashing, and men wildly shouting and gesticulating. One day, one of the more patient fireman explained to him that all traffic was supposed to pull over to the curb and stop when an emergency vehicle approached from the rear. Confident that he now understood the rationale for it, the next time a fire truck rushed up from behind he immediately pulled to the curb. When the firemen waved and shouted even more vigorously than before, Dr. WARKany was understandably somewhat disturbed. Finally, the firemen made it clear that the rule did not apply when the house in front of which he had parked, happened to be the one that was on fire.

Any of you who have traveled with him are probably familiar with the WARKANY 'noise-at-night' syndrome. He stoutly maintains that he almost never gets a good night's sleep away from home, because someone or something conspires to make loud noises during the night-either the street below is being torn up with a pneumatic hammer, the elevator next door rumbles and rattles, the radiator bangs and hisses, or a convention is in progress in the hall outside his door-all despite the fact that he always asks the room clerk to give him a quiet room. Recently, he asked his secretary to request an advanced reservation with a hotel chain that advertizes computerized confirmation of reservations; as usual he asked for a quiet room. When a message came back that their computer was not programmed to reserve quiet rooms, Dr. WARKANY was heard to remark: 'Well, that figures, I never trusted computers any more than I did hotel room clerks'.

A few pictures further show the human side of the man you honor today. The Navigator testing the breeze with a moistened forefinger (fig. 4), and the Lover-of the great out-of-doors, taken at the King Ranch in Texas (fig. 5). It has been commented upon before that 
men of medicine, with surprising frequency, have greater than ordinary capability in one or another of the arts. JOE WARKANY has considerably greater than ordinary capability in the art of etching (figs. 6 and 7). This most monumental creative effort, however, will be the one now in the final stages of completion. I refer to the compendium entitled Congenital Malformations, which deals with the etiology and clinical manifestations of congenital diseases. He has worked diligently for more than 10 years on this exhaustive assimilation of knowledge and I look forward to its publication early in 1971 as a major milestone, not just for the field of teratology, but for the whole of human biology [2].

It is indeed a privilege and an honor to present $\mathrm{Mr}$. Teratology himself, Dr. Josef Warkany.
References and $\mathcal{N}$ otes

1. Nelson, W.E.: Textbook of pediatrics (Saunders, Philadelphia 1959).

2. WARkANy, J.: Congenital malformations (Yearbook Medical, Chicago 1971).

3. Requests for reprints should be addressed to: J.G. Wilson, Ph. D., Children's Hospital Research Foundation, Elland Avenue and Bethesda, Cincinnati, OH 45229 (USA).

4. Accepted for publication June 9, 1970. 